\title{
Cultivable Nitrogen Fixing Bacteria from Extremely Alkaline-Saline Soils
}

\author{
Yendi E. Navarro-Noya ${ }^{1}$, Marco Luna-Guido², Luc Dendooven² \\ ${ }^{1}$ CONACYT-Tlaxcala Autonomous University, Tlaxcala, Mexico \\ ${ }^{2}$ Laboratory of Soil Ecology, ABACUS-Cinvestav, Mexico City, Mexico \\ Email: "nyendi@hotmail.com, yenavarrono@conacyt.mx
}

Received 10 March 2016; accepted 8 May 2016; published 13 May 2016

Copyright (C) 2015 by authors and Scientific Research Publishing Inc.

This work is licensed under the Creative Commons Attribution-NonCommercial International License (CC BY-NC).

http://creativecommons.org/licenses/by-nc/4.0/

(c) (1) (9) Open Access

\section{Abstract}

Three soils with different Electrolytic Conductivity (EC) from the former Lake Texcoco (soil with low EC $1.2 \mathrm{dS} \cdot \mathrm{m}^{-1}$, medium with EC $83.1-107.8 \mathrm{dS} \cdot \mathrm{m}^{-1}$, and high with EC $137.3-152.5 \mathrm{dS} \cdot \mathrm{m}^{-1}$ ) were used to isolate nitrogen-fixing bacterial strains through enrichment cultures in nitrogen-free media. The medium and high EC in the soil affected negatively the nitrogen-fixing activity, which was generally ten times lower compared to the activity in the soil with low EC. Twenty-one bacterial strains were isolated, identified and characterized for their nitrogen fixation capacity. The diazotrophic genetic potential of all isolates was confirmed by amplification and sequencing of partial nifH and nifD genes and diazotrophic activity quantified by the acetylene reduction assay. Azospirillum brasilense, and several species of Paenibacillus (P. fujiensis, P. durus, P. borealis, $P$. graminis, $P$. massiliensis and $P$. wynnii) were identified. Isolates belonging to the Paenibacillus genus were found in the three soils. Paenibacillus fujiensis and $P$. durus showed a high nitrogenase activity. The phylograms based on nifH and nifD gene sequences were consistent with $16 \mathrm{~S}$ rRNA gene phylogeny.

\section{Keywords}

Diazotrophs, Extremophyles, Haloalkaline, Halotolerant, Paenibacillus

\section{Introduction}

Globally, saline soils or solonchaks cover between 260 million and 340 million ha [1] [2]. Antropogenic activi-

\footnotetext{
${ }^{*}$ Corresponding author.
} 
ties, such as irrigation and excessive use of fertilizer, have increased salt contents in important agriculture production areas affecting soil processes and limiting crop production. Excessive amounts of salts often result in poor soil structure and affect chemical and biological processes [3]-[6]. Saline soils are of particular interest as they allow investigating the effect of high salt contents on microbial activity in a natural environment [6]-[9].

Biological nitrogen fixation controls soil fertility as it represents the most important input of nitrogen into an ecosystem. Activity of nitrogen fixating bacteria, however, is often inhibited by large concentrations of salts [10]-[13]. Nevertheless, Sorokin et al. [12] demonstrated that diazotrophs might still be active in soda soils with moderate salinity and alkalinity. Isolation of pure cultures of haloalkaliphilic diazotrophs from several locations in Central Asia and Egypt through micro-oxic enrichments of soils yielded the aerotolerant fermentative haloalkaliphilic bacterium Amphibacillus tropicus and the obligately anaerobic haloalkaliphile Bacillus arseniciselenatis. Apparently, nitrogen fixing activity in alkaline saline soils can be attributed to free-living fermentative low- GC gram-positive bacteria [10] [13]-[15].

Most studies on nitrogen fixation activity in soils with high salinity have focused on Rhizobium-legume symbioses. Nodule formation on legumes is more sensitive to salt or osmotic stress than the rhizobia. Salt stress inhibits the initial steps of Rhizobium-legume symbioses or affects legume root-hair morphology [11]. Another group of diazotrophs well described in salt stressed environments are the haloalkaliphile cyanobacteria found to be responsible for nitrogen fixation in soda lakes and soils [16]-[18]. Only a few obligate anaerobes isolated from soda lakes, such as Clostridium alkalicellum [19] and Geoalkalibacter ferrihydritucus [20], have been described as diazotrophs.

The soil of the former Lake Texcoco located in the valley of Mexico City (Mexico) can be classified as soda solonchaks. Its $\mathrm{pH}$ ranges from 8.3 to 10.2, electrolytic conductivities (EC) in saturation extracts from 1.2 to 200 $\mathrm{dS} \cdot \mathrm{m}^{-1}$, exchangeable sodium percentages from $75 \%$ to $98 \%$ and sodium adsorption ratio from 103 to $1718 \mathrm{mM}$ [21]. High evaporation rate and low precipitation $\left(700 \mathrm{~mm} \cdot \mathrm{y}^{-1}\right)$ increase the concentration of salts. Dynamics of $\mathrm{C}$ and $\mathrm{N}$ have been investigated intensively [22], and although the bacterial and archaeal communities have been studied [21] [23] [24], no potential diazotrophs have been identified. It can be speculated, however, that nitrogen fixation represents an important input of nitrogen into the environment so diazotrophs should be present. The aim of this work was to determine the nitrogen fixing activity in soils with different electrolytic conductivity, and to identify the cultivable diazotrophic community and to evaluate their potential of nitrogen fixing capacity.

\section{Materials and Methods}

\subsection{Sampling and Sample Description}

Three soils from the former Lake Texcoco $\left(19^{\circ} 30^{\prime} \mathrm{N}, 98^{\circ} 59^{\prime} \mathrm{W}\right)$ with different electrolytic conductivity (EC) were sampled in triplicate. As such, nine soil samples were obtained. Soil was sampled by augering the 0 - 10 $\mathrm{cm}$ layer of a $1 \mathrm{~m}^{2}$-delimited area 20 times while the $0-2 \mathrm{~cm}$ layer was discarded. Soil samples were transported to the laboratory in black polyethylene bags on ice, $5 \mathrm{~mm}$ sieved separately and stored at $-20^{\circ} \mathrm{C}$ pending analysis.

Soil physicochemical characteristics were determined as described previously [25]. The EC was measured in a saturated solution extract and $\mathrm{pH}$ was measured in 1:2.5 soil- $\mathrm{H}_{2} \mathrm{O}$ suspensions using a glass electrode (Table 1). The first soil had a low EC of $1.2 \mathrm{dS} \cdot \mathrm{m}^{-1}$ (considered the Tex-Low soil), the second soil had an EC ranging from 83.1 to $107.8 \mathrm{dS} \cdot \mathrm{m}^{-1}$ (considered the Tex-Med soil), while the third sample had EC ranging from 137.3 to $152.5 \mathrm{dS} \cdot \mathrm{m}^{-1}$ (considered the Tex-High soil). According to the FAO soil classification, a very strong saline soil has an electrolytic conductivity (EC) $>16 \mathrm{dS} \cdot \mathrm{m}^{-1}[26]$.

\subsection{Culture Enrichments and Isolation of Free Living Nitrogen-Fixing Bacterial Cultures}

Diazotrophic enrichment cultures were obtained by adding subsamples of $0.5 \mathrm{~g}$ soil to $125 \mathrm{ml}$ serum-flasks containing $100 \mathrm{ml} \mathrm{N}$-free semisolid medium [27]. The medium contained (g. $\mathrm{l}^{-1}$ ): $0.1, \mathrm{MgSO}_{4} \cdot 7 \mathrm{H}_{2} \mathrm{O} ; 0.5$, sodium thioglycolate; 0.008 , ferric citrate; $0.008, \mathrm{Na}_{2} \mathrm{MoO}_{4} \cdot 2 \mathrm{H}_{2} \mathrm{O}$, and agar $0.1 \%(\mathrm{w} / \mathrm{v})$. The medium was autoclaved at $121^{\circ} \mathrm{C}$ for $15 \mathrm{~min}$. After sterilization, the medium was supplemented with $55 \mathrm{mM}$ filter-sterilized glucose and phosphate buffer ( $36 \mathrm{mM} \mathrm{K}_{2} \mathrm{HPO}_{4}$ and $16 \mathrm{mM} \mathrm{NaH}_{2} \mathrm{PO}_{4}$ ). Serum flasks were stoppered with cotton plugs and incubated statically at $22^{\circ} \mathrm{C}$ for several days. When turbidity appeared, the flasks were closed with sterile rubber stoppers, acetylene added and nitrogenase activity measured after one day. Positive cultures were stabilized by repeated transfers ( $1 \%$ inoculum) with an interval of two weeks. 
Table 1. Nitrogen fixation activity in soils of the former Lake Texcoco with different electrolytic conductivity.

\begin{tabular}{ccccc}
\hline & & \multicolumn{3}{c}{ Acetylene reduction assay $\left(\mathrm{nmol} \mathrm{C}_{2} \mathrm{H}_{4} \mathrm{~h}^{-1} \cdot \mathrm{g}^{-1}\right.$ soil) } \\
\cline { 3 - 5 } Soil & & 1 & 2 & 3 \\
Tex-Low & 1.2 & $\left.172(69)^{\mathrm{b}}\right)$ & $296(55)$ & $255(57)$ \\
Tex-Med & $83-108$ & $47(33)$ & $16(6)$ & $16(6)$ \\
Tex-High & $137-153$ & $30(12)$ & $8(4)$ & $30(10)$ \\
\hline
\end{tabular}

${ }^{\mathrm{a}}$ EC: Electrolytic conductivity. ${ }^{\mathrm{b}}$ Values between parenthesis are standard deviations of the mean.

Nitrogen fixing bacteria were isolated in solid N-free culture medium. Serial decimal dilutions of enrichment cultures in sterile water were done and $10^{-5}$ to $10^{-9}$ dilutions were spread onto N-free Bridges agar and incubated in an atmosphere enriched with GasPack ${ }^{\circledR}$ system at $28^{\circ} \mathrm{C}$ for five days. Five representative colonies of each morphotype obtained were used to confirm nitrogenase activity by the acetylene reduction assay. The positives were conserved in $25 \% \mathrm{v} / \mathrm{v}$ glycerol at $-70^{\circ} \mathrm{C}$.

\subsection{Differentiation of Pure Cultures and 16S rRNA Gene Sequence Analysis}

Random amplification polymorphic DNA (RAPD) fingerprints were obtained to distinguish morphologically similar strains. Briefly, genomic DNA from the isolates was obtained from $48 \mathrm{~h}$ bacterial cultures with a QIAamp DNA minikit (Qiagen Inc., Valencia, CA) on the QIAcube ${ }^{\circledR}$ apparatus (Qiagen). Extracted bacterial DNA was eluted from the columns with $200 \mu \mathrm{l}$ elution buffer and stored at $-20^{\circ} \mathrm{C}$.

The RAPD fingerprints were generated using the primer OPB01 (5'-GTT TCG CTC C-3') and the reaction conditions were used as previously reported [28]. The RAPD products were electrophoresed in 1.5\% agarose gels in $1 \times$ TAE (40 mM Tris, pH 8.3; 20 mM acetic acid; 1 mM EDTA) and stained with SYBR® Gold (Invitrogen Corporation, Carlsbad, CA).

At least two isolates of each group were selected for identification by a similitude and phylogenetic analysis of the 16S rRNA gene partial sequence. The amplification of 16S rRNA genes was done using the universal bacterial primer 8 forward and 1492 reverse [29]. The PCR products were purified using the QIAquick PCR purification kit according to manufacturer's instructions (Qiagen Inc., Valencia, CA). Sequencing was done by Macrogen Inc. (DNA Sequencing Service, Seoul, Korea).

\subsection{Molecular Analyses of nifH and nifD Genes}

The nifH and nifD genes fragments were amplified from chromosomal DNA samples using primers designed for this work. These primers were chosen from conserved regions detected in multiple sequence (nucleotidic and aminoacidic) alignments of a broad collection of nif $\mathrm{H}$ and nif $\mathrm{D}$ genes and design degenerate primer pairs. The designed primers correspond to N19-N38 (5'-TAY GGI AAR GGI GGI ATH GG-3’) and N378-N398 (5’-GGI GAY GTI GTI TGY GGI GGI-3') of nifH Methanocaldococcus jannaschii MJ-4000-136 (DQ516852), and N181-N200 (5’-CGC GGC TGC GCC TAY GCM GG-3’) and N1309-N1328 (5’-CCK TTC CGY CAG ATG CAY TC-3') of nifD Klebsiella pneumoniae (X13303). The PCR reactions were done with an initial denaturation step at $94^{\circ} \mathrm{C}$ for $10 \mathrm{~min}, 35$ cycles at $94^{\circ} \mathrm{C}$ for $60 \mathrm{~s}$, at $55^{\circ} \mathrm{C}$ for $60 \mathrm{~s}$, and at $72^{\circ} \mathrm{C}$ for $60 \mathrm{~s}$ and a final extension at $72^{\circ} \mathrm{C}$ for $10 \mathrm{~min}$. Reactions contained $20 \mathrm{ng}$ template DNA, $1 \times$ reaction buffer, $50 \mathrm{mM} \mathrm{MgCl}, 0.25 \mathrm{mM}$ of each dNTP, $10 \mathrm{pM}$ of each primer and $1 \mathrm{U}$ Taq polymerase, adjusted to $25 \mu \mathrm{l}$. Purified PCR products were sequenced by Macrogen Inc.

\subsection{Phylogenetic Analysis}

Taxonomic assignations were done with the RDP classifier 2.2 at an 80\% confidence threshold [30] and based on the Greengenes reference database (version 1210). A collection of taxonomically related sequences obtained from the national center for biotechnology information (NCBI) taxonomy homepage

(http://www.ncbi.nlm.nih.gov/Taxonomy/taxonomyhome.html/) and Ribosomal Database Project-II Release 10 (http://rdp.cme.msu.edu) were used for a multiple alignment analyses with CLUSTAL X [31]. Only common 16S rRNA gene regions were included in the phylogenetic analyses. Maximum likelihood analyses were done 
using MEGA version 5 [32]. "Find best model" tool were used to evaluate the substitution models. For each model, AICc value (Akaike Information Criterion, corrected), Maximum Likelihood value $(\ln L)$, and the number of parameters (including branch lengths) were calculated [33]. The confidence at each node was assessed by 500 bootstrap replicates [34]. The similitude percentages were obtained by subtracting p-distance from one.

\subsection{Acetylene Reduction Assay}

The nitrogen-fixation (NF) activity of the enrichment-cultures and pure cultures was examined by means of the acetylene reduction activity assay (ARA) as reported by Navarro-Noya et al. [28]. Briefly, strains were grown in $10 \mathrm{ml}$ vials containing $5 \mathrm{ml} \mathrm{N}$-free semisolid medium to determine their nitrogenase activity. A single colony of each bacterial strain was incubated at $30^{\circ} \mathrm{C}$ for $72 \mathrm{~h}$. The vials were sealed with rubber stoppers and acetylene was injected to a final concentration of $5 \%(\mathrm{v} / \mathrm{v})$ by replacing an identical volume of air. The test tubes were incubated at $30^{\circ} \mathrm{C}$ for 12 or $24 \mathrm{~h}$. The produced ethylene was measured with an Agilent 4890-D GC-17 gas chromatograph (USA). The gas chromatograph was fitted with a $0.2 \mathrm{ml}$ sample loop on the injector port, a 50/80 Porapak N column $(182.88 \mathrm{~cm}$ by $3.175 \mathrm{~mm})$ and a flame ionization detector. The temperature of the injector was $40^{\circ} \mathrm{C}$, the detector $250^{\circ} \mathrm{C}$ and the oven $55^{\circ} \mathrm{C}$. Concentrations of ethylene were calculated every time samples were analysed by comparing peak areas against a standard curve prepared from a standard concentration of 250 ppm ethylene. Reference strain Klebsiella variicola ATCC BAA-830T was included as positive and Escherichia coli DH10b as negative control.

Total cell protein concentration in the semisolid medium used to determine ARA was measured by the coomassie brilliant blue assay [35]. Bovine serum albumin (sigma no. A5503, Grade V, 99\% purity) was used as standard. Prior to the protein determination, the sample was incubated with $10 \%(\mathrm{w} / \mathrm{v})$ trichloroacetic acid at $90^{\circ} \mathrm{C}$ for $20 \mathrm{~min}$, then cooled to room temperature and centrifuged at $8000 \times \mathrm{g}$ for $15 \mathrm{~min}$ [36]. The insoluble protein was disolved in $0.1 \mathrm{M} \mathrm{NaOH}$ at $55^{\circ} \mathrm{C}$ for $1 \mathrm{~h}$. Semisolid medium without inoculum were processed as control.

\subsection{Determination of Tolerance to $\mathrm{NaCl}$}

Tolerance to $\mathrm{NaCl}$ was determined by broth microdilution according to the CLSI document M27-A2 (2002). $\mathrm{NaCl}$ concentrations were varied from $0 \%$ to $25 \%$ with $1 \%$ increments. Briefly, an inoculum suspension was adjusted to a 0.5 McFarland standard and diluted first 1:50 and then 1:20 in R2A medium. Medium R2A contained $\left(\mathrm{g} \cdot \mathrm{l}^{-1}\right.$ ): 0.5 , yeast extract; 0.5 , proteose peptone (Difco no. 3); 0.5 , casamino acids; 0.5 g, glucose; 0.5 , soluble starch; 0.3, sodium pyruvate; $0.3, \mathrm{~K}_{2} \mathrm{HPO}_{4} ; 0.05, \mathrm{MgSO}_{4} \cdot 7 \mathrm{H}_{2} \mathrm{O} ; \mathrm{pH} 7.2$ [37]. The minimum inhibitory concentration (MIC) microplates were incubated at $28^{\circ} \mathrm{C}$ until growth in the medium without $\mathrm{NaCl}$.

\subsection{Sequence Accession Numbers}

The sequence data reported in this paper have been deposited in the GenBank database, under accession numbers from JQ436863-JQ436919.

\section{Results}

\subsection{Measurements of Nitrogen Fixation Activity in Enrichment Cultures}

Nitrogen fixation rate in the Tex-Low soil varied from 172 to $296 \mathrm{nmol} \mathrm{C}_{2} \mathrm{H}_{4} \mathrm{~h}^{-1} \cdot \mathrm{g}^{-1}$ soil, while in the Tex-High soil from 7.4 to $30.4 \mathrm{nmol} \mathrm{C} \mathrm{C}_{4} \mathrm{H}^{-1} \cdot \mathrm{g}^{-1}$ soil (Table 1). Stabilized cultures were obtained after six transfers in $\mathrm{N}$-free medium. Nitrogenase activity in the stabilized cultures of the Tex-Low was $14.2 \mathrm{C}_{2} \mathrm{H}_{4} \mathrm{~h}^{-1}$. culture ${ }^{-1}$, in Tex-Med $4.3 \mathrm{C}_{2} \mathrm{H}_{4} \mathrm{~h}^{-1}$. culture ${ }^{-1}$ and in Tex-High $4.8 \mathrm{nmol} \mathrm{C}_{2} \mathrm{H}_{4} \mathrm{~h}^{-1}$. culture ${ }^{-1}$ (data not shown). Gram-positive spore-forming bacilli dominated in all the enrichment cultures.

\subsection{Isolation and Identification of Diazotrophic Strains}

A total of 39 strains with positive AR activity were isolated from the enrichment cultures. However, after RAPD screening 21 different RAPD-profiles were found (Data not shown). Seven different profiles were found in the Tex-Low soil, 10 in the Tex-Med soil and four in the Tex-High soil.

Strains Tex01-S1, Tex01-S2, Tex01-S3, Tex01-S5, Tex22-S1, Tex02-S4, Tex03-P3, Med01-S2 and Hgh02- 
P1 were isolated in consortium with negative NF isolates. Consortiums were more frequent in soil with low EC.

Approximately 1430 nucleotides of 16S rRNA gene sequence of each isolate were used for identification based on pair alignments with sequences from databases and relationships in a phylogenetic tree. A majority of the isolates belonged to the genus Paenibacillus ( $P$. durus, $P$. graminis, $P$. wynnii, $P$. massiliensis, $P$. borealis and $P$. fujiensis), with similarity percentages of 99.1 - 100 (Table 2). Only three of the isolates were identified as Azospirillum brasilense (Tex03-P3, Tex02-S3 and Tex02-S3c) and were detected in the Tex-Low sample soil. Paenibacillus durus and $P$. fujiensis were isolated from the Tex-Low soil, $P$. durus and $P$. graminis from TexMed and $P$. borealis, $P$. massiliensis and $P$. wynii from Tex-High soil.

Consortium members with negative NF activity were also analyzed for identification. Thus, Agrobacterium tumefaciens, Celullomonas hominis, Bacillus circulans, Achromobacter xylosoxidans and Pantoea agglomerans were found (Table 2).

\subsection{Characterization of the Nitrogen-Fixing Isolates}

Nitrogen fixation capacity of the isolates was investigated by PCR-amplification of nifH and nifD genes and quantified by ARA (Table 3). Except for the Hgh03-P4 isolate, nif genes were detected in all strains. In general, higher NF activities were found in isolates from the Tex-Low soil. Strains with a high activity (2811 - 4358 nmol $\mathrm{C}_{2} \mathrm{H}_{4} \mathrm{~h}^{-1} \cdot \mathrm{mg} \cdot$ protein $^{-1}$ ) were Tex01-S5 and Tex02-S5 identified as $P$. fujiensis (first two) and Md01-S1 as P. durus. Strains Tex01-S4, Tex02-P4 and Tex02-S4 showed an NF activity of approximately $1500 \mathrm{nmol} \mathrm{C}_{2} \mathrm{H}_{4}$ $\mathrm{h}^{-1} \cdot \mathrm{mg} \cdot$ protein $^{-1}$.

The isolates grew in medium containing $2 \%-10 \% \mathrm{NaCl}$. Isolates with a tolerance to $10 \% \mathrm{NaCl}$ were $\mathrm{Hgh} 02-$ S1, Hgh02-S1 and Tex01-S5. There was no relationship between source of isolation (soil with low, medium or

Table 2. Phylogenetic affiliation of nitrogen-fixing isolates from soils of the former Lake Texcoco.

\begin{tabular}{|c|c|c|c|}
\hline Soil & Bacterial strain (GenBank accession number) & Best match ${ }^{\mathrm{a}}$ (GenBank accession number) & Similarity $^{\mathrm{b}}(\%)$ \\
\hline \multirow[t]{8}{*}{ Tex-Low } & Tex01-S4 (JQ436894); Tex02-S4 (JQ436895) & Paenibacillus durus (NR_037017) & 100 \\
\hline & $\begin{array}{c}\text { Tex01-S5 (JQ436893); Tex02-S5 (JQ436897); } \\
\text { Tex02-P4 (JQ436896) }\end{array}$ & Paenibacillus fujiensis (AB092351) & 100 \\
\hline & $\begin{array}{c}\text { Tex03-P3 (JQ436891); Tex02-S3 (JQ436890); } \\
\text { Tex02-S3c (JQ436892) }\end{array}$ & Azospirillum brasilense (EF634031) & $99-99.2$ \\
\hline & $\begin{array}{c}\text { Tex03-P3c (JQ436912); Tex01-S2c (JQ436913); } \\
\text { Tex01-S3c (JQ436914) }\end{array}$ & Bacillus circulans (JN644554) & 99.1 \\
\hline & Tex01-S5c (JQ436888); Tex01-S3b (JQ436889) & Agrobacterium tumefaciens (AJ389909) & 98.7 \\
\hline & Tex02-S1c (JQ436918) & Pantoea agglomerans (AM184264) & 100 \\
\hline & Tex01-S2a (JQ436919) & Achromobacter xylosoxidans (FJ796451) & 100 \\
\hline & Tex01-S1c (JQ436916) & Celullomonas hominis (AB480700) & $99-100$ \\
\hline \multirow[t]{3}{*}{ Tex-Med } & $\begin{array}{l}\text { Md01-S1 (JQ436900); } \\
\text { Md01-S4 (JQ436898); } \\
\text { Md01-S5 (JQ436899) }\end{array}$ & Paenibacillus durus (NR_037017) & $99.5-99.8$ \\
\hline & $\begin{array}{l}\text { Md02-S1 (JQ436905); } \\
\text { Md02-S3 (JQ436901); } \\
\text { Md03-S1 (JQ436902); } \\
\text { Md03-S2 (JQ436907); } \\
\text { Md03-S3 (JQ436904); } \\
\text { Md03-S5 (JQ436903); } \\
\text { Md03-S6 (JQ436906) }\end{array}$ & Paenbacillus graminis (AM745263) & 99.6 \\
\hline & Med01-S2c (JQ436915) & Bacillus circulans (JN644554) & 99.9 \\
\hline \multirow[t]{3}{*}{ Tex-High } & Hgh02-S4 (JQ436909); Hgh02-P4 (JQ436908) & Paenibacillus borealis (AB073364) & $99.1-99.6$ \\
\hline & Hgh02-S1 (JQ436911); Hgh02-S2 (JQ436910) & Paenibacillus massiliensis (AY912109) & 100 \\
\hline & Hgh02-P1c (JQ436917) & Celullomonas hominis (AB480700) & $97.5-99.8$ \\
\hline
\end{tabular}

${ }^{\mathrm{a}}$ The best match was selected using the closest sequence from the phylogenetic tree. ${ }^{\mathrm{b}}$ Similarity percentage was estimated by considering the number of nucleotide-substitutions between a pair of sequences divided by the total number of compared bases $\times 100$. 
Table 3. Acetylene reduction activity and $\mathrm{NaCl}$ tolerance in nitrogen-fixing isolates from soil of the former Lake Texcoco.

\begin{tabular}{|c|c|c|c|}
\hline Soil & Bacterial strain & Acetylene reduction activity ( $\mathrm{nmol} \mathrm{C}_{2} \mathrm{H}_{4} / \mathrm{h} / \mathrm{mg}$ protein) & $\mathrm{NaCl}$ tolerance $\left.\mathrm{a}^{\mathrm{a}} \%\right)$ \\
\hline \multirow[t]{9}{*}{ Tex-Low } & Tex01-S4 & $1960 \pm 56$ & 2 \\
\hline & Tex01-S5 & $4358 \pm 143$ & 10 \\
\hline & Tex02-S2 & $429 \pm 78$ & 2 \\
\hline & Tex02-S3 & $484 \pm 46$ & 3 \\
\hline & Tex02-S3c & $97 \pm 4$ & 3 \\
\hline & Tex02-S4 & $1722 \pm 76$ & 3 \\
\hline & Tex02-S5 & $2811 \pm 190$ & 3 \\
\hline & Tex02-P4 & $1835 \pm 24$ & 3 \\
\hline & Tex03-P3 & $124 \pm 7$ & 3 \\
\hline \multirow[t]{4}{*}{ Tex-Med } & Md01-S1 & $2982 \pm 699$ & 7 \\
\hline & Md01-S5 & $574 \pm 44$ & 4 \\
\hline & Md02-S1 & $435 \pm 36$ & 2 \\
\hline & Md02-S3 & $399 \pm 29$ & 2 \\
\hline \multirow[t]{5}{*}{ Tex-High } & Hgh02-P4 & $638 \pm 75$ & 3 \\
\hline & Hgh02-S1 & $234 \pm 53$ & 10 \\
\hline & Hgh02-S2 & $324 \pm 78$ & 10 \\
\hline & Hgh02-S4 & $175 \pm 12$ & 4 \\
\hline & Hgh03-P2 & $184 \pm 56$ & 3 \\
\hline
\end{tabular}

${ }^{\mathrm{a}} \mathrm{NaCl}$ tolerance was determined in R2A medium amended with $\mathrm{NaCl}$.

high EC) and $\mathrm{NaCl}$ tolerance.

\subsection{Phylogenetic Analyses}

Maximum-likelihood phylogenetic trees of 16S rRNA, nifH, and nifD genes were constructed to determine relationships between the sequences of the isolates and related organisms from the GenBank database. Phylogenetic trees obtained with 16S rRNA sequences of the diazotrophic isolates and negative NF co-isolates showed that nitrogen-fixing species of the genus Paenibacillus were grouped in three different clusters (Figure 1). Cluster A grouped Tex-Low and Tex-Med isolates, cluster B grouped Tex-Med and Tex-High isolates and cluster C grouped Tex-High isolates. The $16 \mathrm{~S}$ rRNA phylogram also included sequences belonging to the Proteobacteria and the Actinobacteria phyla, which corresponded to ribosomal sequences of the negative NF co-isolates.

Topology of the Maximum-Likelihood nifH tree displays a similar tendency with isolate sequences grouped in three phylogenetic clusters (Figure 2). Cluster A was formed by 7 nifH gene sequences of isolates from the Tex-Med soil and was related to $P$. graminis nifH gene (84\% of identity). Cluster B grouped 3 nifH gene sequences of isolates from the Tex-High soil and were related to P. wynnii nifH (Hgh02-S4 and Hgh02-P4) and P. massiliensis nifH (Hgh02-S2). Cluster C comprised five isolate sequences from the Tex-Low soil and two from the Tex-Med soil. These nifH sequences were related to a compressed group formed by $P$. forsythia, $P$. sabinae, $P$. durus, $P$. zanthoxyli and $P$. fujiensis.

\section{Discussion}

Nitrogen fixation is a key process that is, in part, directly correlated with the primary production of many environments [38] [39]. Together with other processes of the N cycle (e.g. ammonification, nitrification and denitrification), nitrogen fixation is affected by environmental factors, such as temperature, $\mathrm{pH}$, oxygen, heavy metals and mineral nutrients [40]-[42]. Our study documents nitrogen-fixing cultivable bacteria obtained by enrichment 


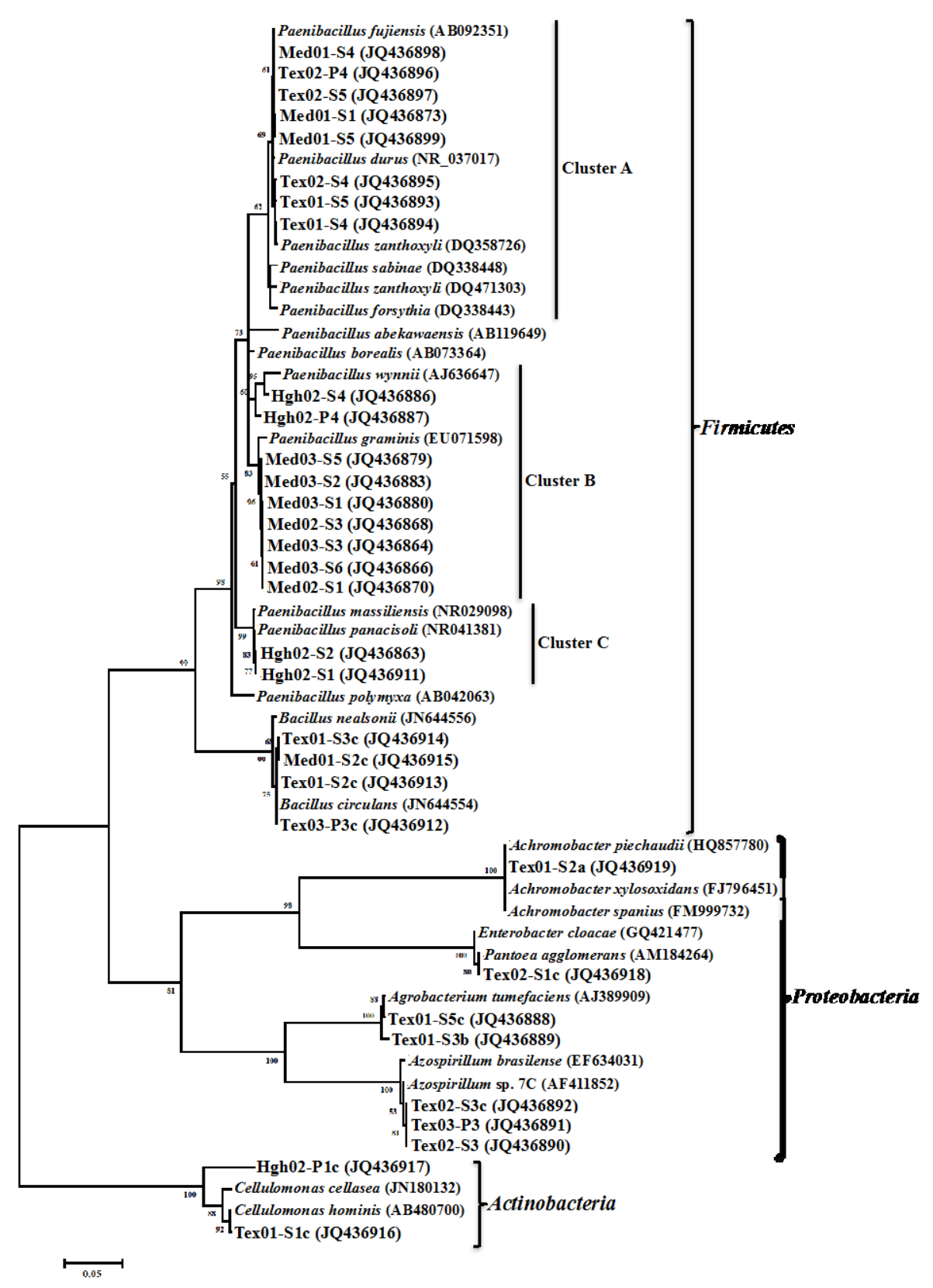

Figure 1. Maximum-likelihood phylogenetic tree showing the position of the 16S rRNA gene fragments amplified from the nitrogen-fixing isolates and consortium coisolates from soils of the former Lake Texcoco. The scale bars indicate the nucleotide substitutions per site. Numbers at the branches indicate the bootstrap values of 500 resamplings. Only values above $50 \%$ are shown. Actinobacteria phylum served as outgroup.

cultures in nitrogen-free media occurring in soils with a different degree of salinity.

$\mathrm{N}_{2}$ fixation rates were obtained (296 nmol $\mathrm{C}_{2} \mathrm{H}_{4} \mathrm{~h}^{-1} \cdot \mathrm{g}^{-1}$ dry soil or $48.5 \mu \mathrm{g} \cdot \mathrm{N} \cdot \mathrm{day}^{-1} \cdot \mathrm{g}^{-1}$ soil), similar to those found in other terrestrial environments, such as in soda solonchak soils and the rhizosphere of some plants [12] [14] [40]. In this work, the high EC, however, affected negatively the nitrogen fixation activity, as it was ten-times lower in Tex-High compared to the Tex-Low soil (Table 1). Different effects of salinity on $\mathrm{N}_{2}$ fixing have been reported. Some studies have found that concentrations of $\mathrm{NaCl}$ as low as $75 \mathrm{mM}$ had a negative effect on nitrogenase activity in symbiotic nitrogen fixers [41]. In mangroves, nitrogen fixation was also reduced when $\mathrm{pH}$ and salinity increased [43]. However, others have reported no negative effects of high salinity on nitrogen 


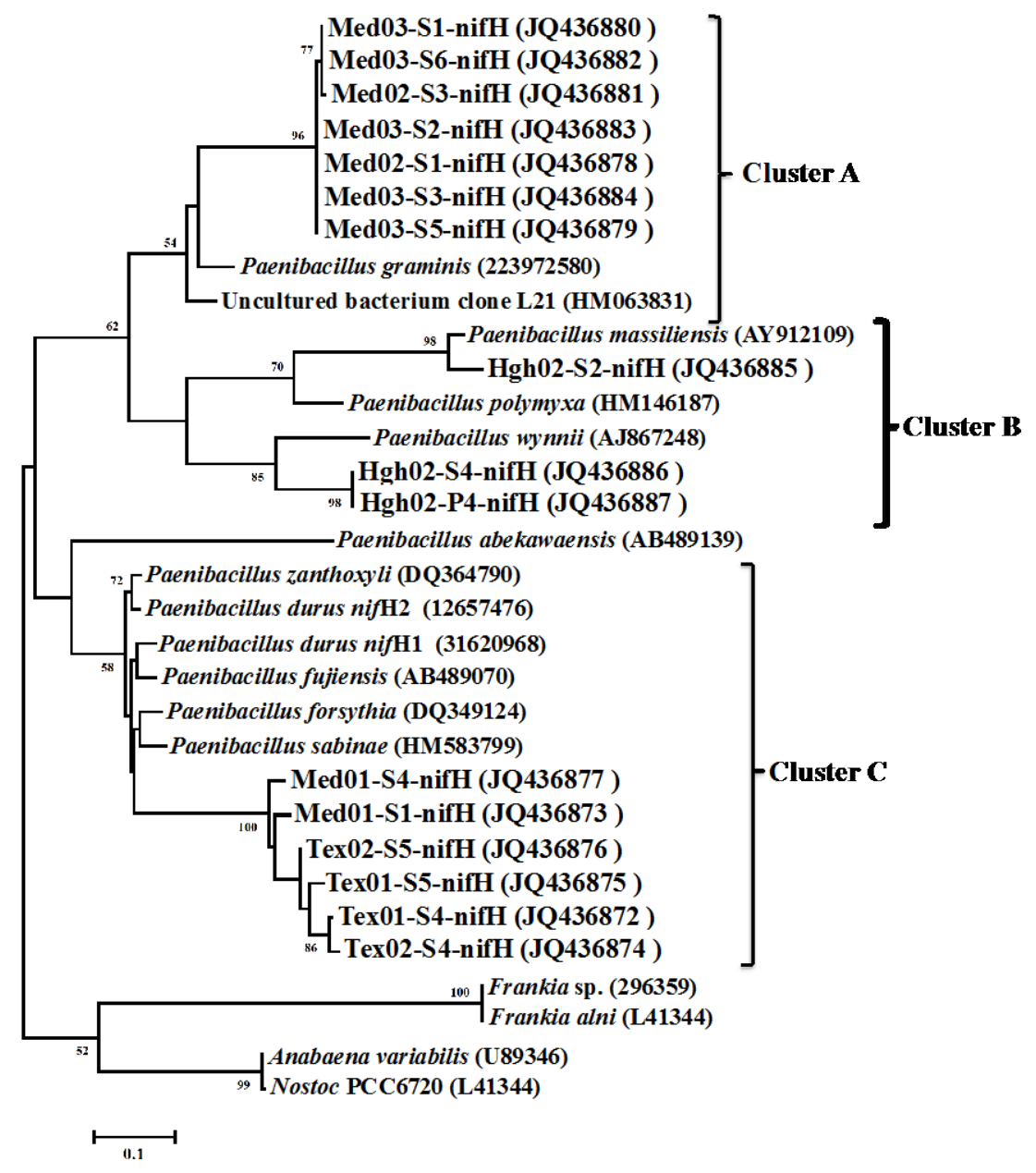

Figure 2. Maximum-likelihood phylogenetic tree showing the position of the nif $\mathrm{H}$ gene fragments amplified from the nitrogen-fixing isolates from soils of the former Lake Texcoco. The scale bars indicate the nucleotide substitutions per site. Numbers at the branches indicate the bootstrap values of 500 resamplings. Only values above $50 \%$ are shown. nifH of Cyanobacteria group served as outgroup.

fixation activity [44].

$\mathrm{pH}$ is also an important factor that affects nitrogen fixation [12] [43] reported that in soda solonchak soils maximum nitrogen fixation activity was obtained at $\mathrm{pH} 9.8$, but at $\mathrm{pH} 7.3$ and 10.5 it decreased $80 \%$. Microorganisms involved in key processes of important biochemical cycles are probably well adapted to extreme conditions. It is possible that the decrease in nitrogen fixation activity in Tex-Med and Tex-High was a synergistic effect of a high salinity and $\mathrm{pH}$.

Isolation of nitrogen-fixing bacteria through enrichment in nitrogen-free media allowed us to identify different species of the Paenibacillus genus and Azospirillum brasilense. Paenibacillus spp. are ubiquitous, and frequently isolated from the rhizosphere of maize, wheat, sugarcane, and pioneer plants growing on mine tailings [28] [45]-[47]. Nitrogen fixing species are also characterized by their capacity to produce phytohormones, solubilize phosphorous and control the access of phytopathogens in plants [45] [46] [48] [49]. In other salt stressed environments, some genera phylogenetically related with Paenibacillus have been isolated, e.g. Amphibacillus tropicus, Bacillus arseniciselenatis in solonchak soils and Bacillus spp. in coastal arable saline soils [12] [15]. In mangrove ecosystem other $\mathrm{N}_{2}$ fixing bacteria have been isolated, e.g. Azospirillum, Azotobacter, Rhizobium, Clostridium, Klebsiella, Vibrio, and Phyllobacterium [50]. This is probably due to the specific physicochemical characteristics of this environment. nifH genes related with $P$. durus were also detected in solochak soils [12]. Particularly, A. brasilense was found only in the soil with low EC indicating its sensitivity to high salt concen- 
trations. Nitrogen fixation activity of isolates Tex01-S4, Tex01-S5, Tex02-P4, Tex02-S4, and Med01-S1 identified as $P$. durus and $P$. fujiensis was high and similar to that of other free-living diazotrophs [51].

Bacillus circulans was co-isolated in consortium with several strains. However, to our knowledge, no reports exist of this species as being a diazotroph or any of the other coisolates Achromobacter, Cellulomonas and Patoea. In this study, no nitrogen fixation activity of these bacteria was observed under the conditions tested.

Halotolerant strains of Bacillus and Paenibacillus were previously isolated from salt mining soils of Russia. However, their nitrogen fixation ability was not tested [52]. Most strains isolated in this work were not able to grow in high or moderate concentrations of $\mathrm{NaCl}$. Isolates Tex01-S5 and Hgh02-S1 identified as P. fujiensis and P. massiliensis, however, tolerated up to $10 \% \mathrm{NaCl}$.

Phylogeny of the 16S rRNA and nifH genes showed a clear effect of EC on the distribution of the Paenibacillus spp. Apparently there is a gradient along soils with low, moderate and high EC. Thus, A. brasilense, P. fujiensis, $P$. durus, $P$. graminis, $P$. wynnii, $P$. borealis, and $P$. massiliensis were isolated in that order in the soils from low to high EC. However, their $\mathrm{NaCl}$ tolerance profile did not match this observation. It is possible that other characteristics than salinity affected the bacterial community, especially in the nitrogen fixing guild.

Phylogeny of the 16S rRNA gene showed a clear relationship between sequences from the databases and sequences of the isolates, with percentages of similitude ranging from $99 \%$ to $100 \%$. nif $\mathrm{H}$ and nifD phylogenies agreed with the ribosomal relationships. Nevertheless, similarity and identity were in the range of $84 \%-95 \%$ and $86 \%$ - 99\%, respectively. Ribosomal phylogram showed a close relationship between the cluster formed by $P$. fujiensis and $P$. durus sequences from the database and sequences of the isolates (Figure 1). However, nifH and nifD phylograms showed a close-fitting group formed by $P$. zanthoxyli, $P$. forsythia, $P$. durus and $P$. fujiensis, and relatively distant related isolates (Figure 2, Figure 3 ). This suggests that they might be different ecotypes of this species and selected by the extreme conditions of this soil.

\section{Conclusion}

The results of this investigation concluded that despite extreme salinity and $\mathrm{pH}$ conditions, an active bacterial population with a nitrogen fixation potential was found in the soil of the former Lake Texcoco. The cultivable nitrogen-fixing guild in this environment was mainly represented by Paenibacillus spp.

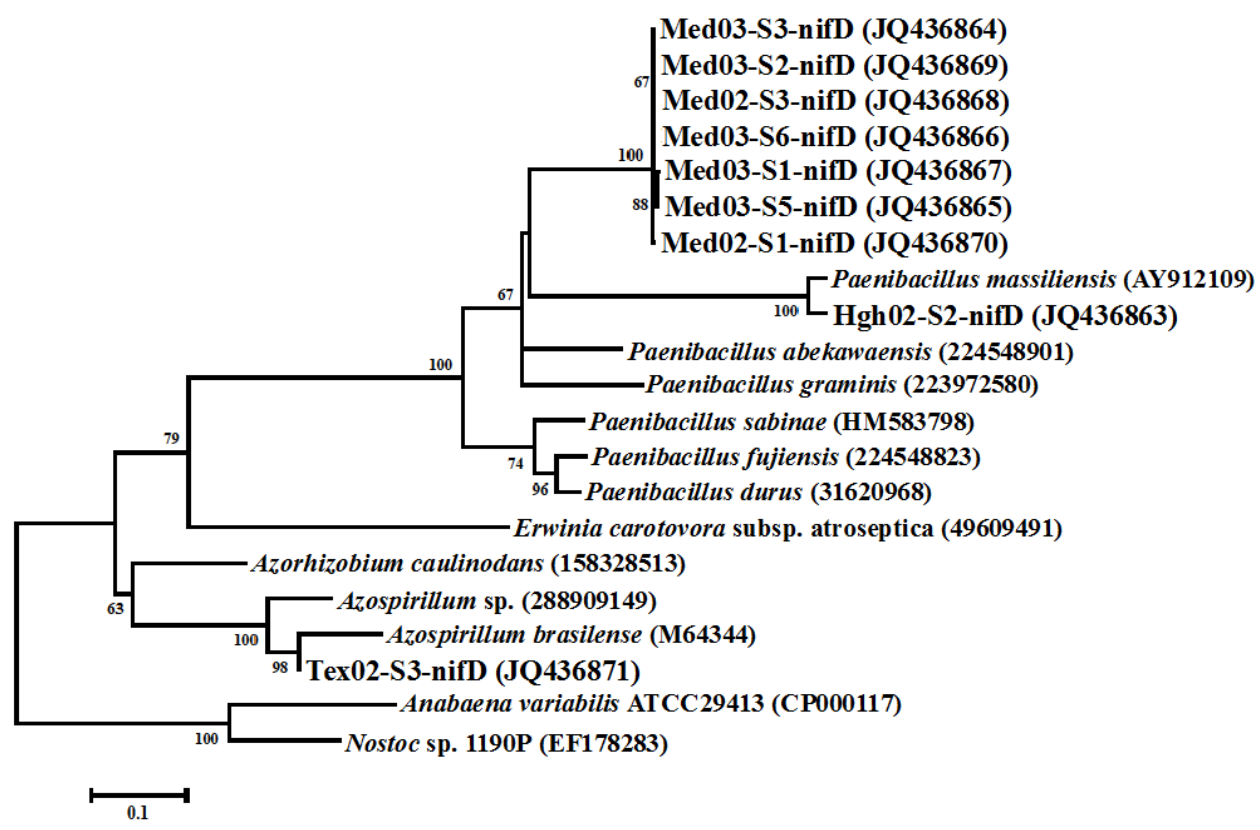

Figure 3. Maximum-likelihood phylogenetic tree showing the position of the nifD gene fragments amplified from the nitrogen-fixing isolates from soils of the former Lake Texcoco. The scale bars indicate the nucleotide substitutions per site. Numbers at the branches indicate the bootstrap values of 500 resamplings. Only values above $50 \%$ are shown. nifD of Cyanobacteria group served as outgroup. 


\section{Acknowledgements}

This research was funded by Centro de Investigación y de Estudios Avanzados (CINVESTAV) and Y. E. Navarro-Noya received a postdoctoral grant BM11-132 from Instituto de Ciencia y Tecnología del Distrito Federal (ICyTDF, Mexico).

\section{References}

[1] Dudal, R. (1990) An International Reference Base for Soil Classification (IRB). In: Transactions of 14th International Congress of Soil Science, Vol. 5, Kyoto, 38-43.

[2] Szabolcs, I. (1989) Salt-Affected SOILS. CRC Press Inc., Boca Raton.

[3] Bernstein, N. and Kafkafi, U. (2002) Root Growth Salinity stress. In: Waisel, Y., Eshel, A. and Kafkafi, U., Eds., Plant Roots “The Hidden Half”, 3rd Edition, The Hebrew University of Jerusalem Rehovot and Tel Aviv University, Israel, 787-805. http://dx.doi.org/10.1201/9780203909423.ch44

[4] Garcia-Orenes, F., Guerrero, C., Mataix-Solera, J., Navarro-Pedreno, J., Gomez, I. and Mataix-Beneyto, J. (2005) Factors Controlling the Aggregate Stability and Bulk Density in Two Different Degraded Soils Amended with Biosolids. Soil and Tillage Research, 82, 65-76. http://dx.doi.org/10.1016/j.still.2004.06.004

[5] Tejada, M., Garcia, C., Gonzalez, J.L. and Hernandez, M.T. (2006) Use of Organic Amendment as a Strategy for Saline Soil Remediation: Influence on the Physical, Chemical and Biological Properties of Soil. Soil Biology and Biochemistry, 38, 1413-1421. http://dx.doi.org/10.1016/j.soilbio.2005.10.017

[6] Quantin, C., Grunberger, O., Suvannang, N. and Bourdon, E. (2008) Land Management Effects on Biogeochemical Functioning of Salt-Affected Paddy Soils. Pedosphere, 18, 183-194. http://dx.doi.org/10.1016/S1002-0160(08)60006-5

[7] Sumner, M.E. (1995) Sodic Soils: New Perspectives. In: Naidu, R., Sumner, M.E., Rengasamy, P., Eds., Australian sodic Soils: Distribution, Properties and Management, CSIRO, Melbourne, 1-34.

[8] Rietz, D.N. and Haynes, R.J. (2003) Effects of Irrigation-Induced Salinity and Sodicity on Soil Microbial Activity. Soil Biology and Biochemistry, 35, 845-854. http://dx.doi.org/10.1016/S0038-0717(03)00125-1

[9] Rengasamy, R. (2006) World Salinization with Emphasis on Australia. Journal of Experimental Botany, 57, 10171023. http://dx.doi.org/10.1093/jxb/erj108

[10] Zahran, H.H., Ahmad, M.S. and Afkar, E.A. (1995) Isolation and Characterization of Nitrogen-Fixing Moderate Halophilic Bacteria from Saline Soils of Egypt. Journal of Basic Microbiology, 35, 269-275. http://dx.doi.org/10.1002/jobm.3620350412

[11] Zahran, H.H. (1999) Rhizobium-Legume Symbiosis and Nitrogen Fixation under Severe Conditions and in an Arid Climate. Microbiology and Molecular Biology Reviews, 63, 968-989.

[12] Sorokin, I.D., Kravchenko, I.K., Doroshenko, E.V., Boulygina, E.S., Zadorina, E.V., Tourova, T.P. and Sorokin, D.Y. (2008) Haloalkaliphilic Diazotrophs in Soda Solonchak Soils. FEMS Microbiology Ecology, 65, 425-433. http://dx.doi.org/10.1111/j.1574-6941.2008.00542.x

[13] Moradi, A., Tahmourespour, A., Hoodaji, M. and Khorsandi, F. (2011) Effect of Salinity on Free Living-Diazotroph and Total Bacterial Populations of Two Saline Soils. African Journal of Microbiology Research, 5, 144-148.

[14] Egamberdieva, D. and Kucharova, Z. (2008) Cropping Effects on Microbial Population and Nitrogenase Activity in Saline Arid Soil. Turkish Journal of Biology, 32, 85-90.

[15] Barua, S., Tripathi, S., Chakraborty, A., Ghosh, S. and Chakrabarti, K. (2011) Studies on Non-Symbiotic Diazotrophic Bacterial Populations of Coastal Arable Saline Soils of India. Indian Journal of Microbiology, 51, 369-376. http://dx.doi.org/10.1007/s12088-011-0082-9

[16] Herbst, D.B. (1998) Potential Salinity Limitations of Nitrogen Fixation in Sediments from Mono-Lake. International Journal of Salt Lake Research, 7, 261-274. http://dx.doi.org/10.1007/BF02441878

[17] Zavarzin, G.A., Zhilina, T.N. and Kevbrin, V.V. (1999) The Alkaliphilic Microbial Community and Its Functional Diversity. Mikrobiologia, 68, 503-521.

[18] Zhang, W. and Feng, Y. (2008) Characterization of Nitrogen-Fixing Moderate Halophilic Cyanobacteria Isolated from Saline Soils of Songnen Plain in China. Progress in Natural Science, 18, 769-773. http://dx.doi.org/10.1016/j.pnsc.2008.01.022

[19] Zhilina, T.N., Kevbrin, V.V., Tourova, T.P., Lysenko, A.M., Kostrikina, N.A. and Zavarzin, G.A. (2005) Clostridium alkalicellum sp. nov., an Obligately Alkaliphilic Cellulolytic Bacterium from a Soda Lake in the Baikal Region. Mikrobiologia, 74, 642-653.

[20] Zavarzina, D.G., Kolganova, T.V., Bulygina, E.S., Kostrikina, N.A., Turova, T.P. and Zavarzin, G.A. (2006) 
Geoalkalibacter ferrihydriticus gen. nov., sp. nov., the First Alkaliphilic Representative of the Family Geobacteraceae, Isolated from a Soda Lake. Mikrobiologia, 75, 775-785.

[21] Navarro-Noya, Y.E., Valenzuela-Encinas, C., Sandoval-Yuriar, A., Jiménez-Bueno, N.G., Marsch, R. and Dendooven, L. (2015) Archaeal Communities in a Heterogeneous Hypersaline-Alkaline Soil. Archaea, 2015, Article ID: 646820. http://dx.doi.org/10.1155/2015/646820

[22] Dendooven, L., Alcántara-Hernández, R.J., Valenzuela-Encinas, C., Luna-Guido, M., Perez-Guevara, F. and Marsch, R. (2010) Dynamics of Carbon and Nitrogen in an Extreme Alkaline Saline Soil: A Review. Soil Biology and Biochemistry, 42, 865-877. http://dx.doi.org/10.1016/j.soilbio.2010.02.014

[23] Valenzuela-Encinas, C., Neria-González, I., Alcántara-Hernández, R., Enríquez-Aragón, J., Estrada-Alvarado, I., Hernández-Rodríguez, C., Dendooven, L. and Marsch, R. (2008) Phylogenetic Analysis of the Archaeal Community in an Alkaline-Saline Soil of the Former Lake Texcoco (Mexico). Extremophiles, 12, 247-254. http://dx.doi.org/10.1007/s00792-007-0121-y

[24] Valenzuela-Encinas, C., Neria-González, I., Alcántara-Hernández, R.J., Estrada-Alvarado, I., Zavala-Díaz de la Serna, F.J., Dendooven, L. and Marsch, R. (2009) Changes in the Bacterial Populations of the Highly Alkaline Saline Soil of the Former Lake Texcoco (Mexico) Following Flooding. Extremophiles, 13, 609-621. http://dx.doi.org/10.1007/s00792-009-0244-4

[25] Conde, E., Cardenas, M., Ponce-Mendoza, A., Luna-Guido, M.L., Cruz-Mondragón, C. and Dendooven, L. (2005) The Impacts of Inorganic Nitrogen Application on Mineralization of ${ }^{14} \mathrm{C}$-Labelled Maize and Glucose, and on Priming Effect in Saline Alkaline Soil. Soil Biology and Biochemistry, 37, 681-691. http://dx.doi.org/10.1016/j.soilbio.2004.08.026

[26] FAO (1988) Salt-Affected Soils and Their Management. Soils Bulletin 39. FAO, Rome.

[27] Bridges, J.R. (1981) Nitrogen-Fixing Bacteria Associated with Bark Beetles. Microbial Ecology, 7, 131-137. http://dx.doi.org/10.1007/BF02032495

[28] Navarro-Noya, Y.E., Hernández-Mendoza, E., Morales-Jiménez, J., Jan-Roblero, J., Martínez-Romero, E. and Hernández-Rodríguez, C. (2012) Isolation and Characterization of Nitrogen Fixing Heterotrophic Bacteria from the Rhizosphere of Pioneer Plants Growing on Mine Tailings. Applied Soil Ecology, 62, 52-60. http://dx.doi.org/10.1016/j.apsoil.2012.07.011

[29] Relman, D.A. (1993) Universal Bacterial 16S rRNA Amplification and Sequencing. In: Persing, D.H., Smith, T.F., Tenover, F.C. and White, T.J., Eds., Diagnostic Molecular Microbiology: Principles and Applications, ASM Press, Washington DC, 489-495.

[30] Wang, Q., Garrity, G.M., Tiedje, J.M. and Cole, J.R. (2007) Naïve Bayesian Classifier for rapid Assignment of rRNA Sequences into the New Bacterial Taxonomy. Applied and Environmental Microbiology, 73, 5261-5267. http://dx.doi.org/10.1128/AEM.00062-07

[31] Thompson, J.D., Gibson, T.J., Plewniak, F., Jeanmougin, F. and Higgins, D.G. (1997) The CLUSTAL-X Windows Interface: Flexible Strategies for Multiple Sequence Alignment Aided by Quality Analysis Tools. Nucleic Acids Research, 25, 4876-4882. http://dx.doi.org/10.1093/nar/25.24.4876

[32] Tamura, K., Dudley, J., Nei, M. and Kumar, S. (2007) MEGA4: Molecular Evolutionary Genetics Analysis (MEGA) Software Version 4.0. Molecular Biology and Evolution, 24, 1596-1599. http://dx.doi.org/10.1093/molbev/msm092

[33] Nei, M. and Kumar, S. (2000) Molecular Evolution and Phylogenetics. Oxford University Press, New York.

[34] Hillis, D.M. and Bull, J.J. (1993) An Empirical Test of Bootstrapping as a Method for Assessing Confidence in Phylogenetic Analysis. Systematic Biology, 42, 182-192. http://dx.doi.org/10.1093/sysbio/42.2.182

[35] Bradford, M.M. (1976) A Rapid and Sensitive Method for the Quantitation of Microgram Quantities of Protein Utilizing the Principal of Protein Dye Binding. Analytical Biochemistry, 72, 248-254. http://dx.doi.org/10.1016/0003-2697(76)90527-3

[36] Nelson, D.C., Waterbury, J.B. and Jannasch, H.W. (1982) Nitrogen Fixation and Nitrate Utilization by Marine and Freshwater Beggiatoa. Archives of Microbiology, 133, 172-177. http://dx.doi.org/10.1007/BF00414997

[37] Reasoner, D.J. and Geldreich, E.E. (1985) A New Medium for the Enumeration and Subculture of Bacteria from Potable Water. Applied and Environmental Microbiology, 49, 1-7.

[38] Zehr, J.P., Jenkins, B.D., Short, S.M. and Steward, G.F. (2003) Nitrogenase Gene Diversity and Microbial Community Structure: A Cross-System Comparison. Environmental Microbiology, 5, 539-554. http://dx.doi.org/10.1046/j.1462-2920.2003.00451.x

[39] Capone, D.G. and Knapp, A.N. (2007) Oceanography: A Marine Nitrogen Cycle Fix? Nature, 445, 159-160.

[40] Hèry, M., Philippot, L., Mériaux, E., Poly, F., Le Roux, X. and Navarro, E. (2005) Nickel Mine Spoils Revegetation Attempts: Effect of Pioneer Plants on Two Functional Bacterial Communities Involved in the N-Cycle. Environmental 
Microbiology, 7, 486-498. http://dx.doi.org/10.1111/j.1462-2920.2005.00705.x

[41] Bolaños, L., Martin, M., El-Hamdaoui, A., Rivilla, R. and Bonilla, I. (2006) Nitrogenase Inhibition in Nodules from Pea Plants Grown under Salt Stress Occurs at the Physiological Level and Can Be Alleviated by B and Ca. Plant and Soil, 280, 135-142. http://dx.doi.org/10.1007/s11104-005-2853-8

[42] Černá, B., Rejmánková, E., Snyder, J.M. and Šantrůčková, H. (2009) Heterotrophic Nitrogen Fixation in Oligotrophic Tropical Marshes: Changes after Phosphorus Addition. Hidrobiologia, 627, 55-65. http://dx.doi.org/10.1007/s10750-009-9715-y

[43] Vovides, A.G., Lopez-Portillo, J. and Bashan, Y. (2011) N2-Fixation along a Gradient of Long-Term Disturbance in Tropical Mangroves Bordering the Gulf. Biology and Fertility of Soils, 47, 567-576. http://dx.doi.org/10.1007/s00374-011-0562-4

[44] Zahran, H.H. (1997) Diversity, Adaptation and Activity of the Bacterial Flora in Saline Environments. Biology and Fertility of Soils, 25, 211-223. http://dx.doi.org/10.1007/s003740050306

[45] Seldin, L., Rosado, A.S., da Cruz, D.W., Nobrega, A., van Elsas, J.D. and Paiva, E. (1998) Comparison of Paenibacillus azotofixans Strains Isolated from Rhizoplane, Rhizosphere, and Non-Root-Associated Soil from Maize Planted in Two Different Brazilian Soils. Applied and Environmental Microbiology, 64, 3860-3868.

[46] Albuquerque, J.P., Mota, F.F., von der Weid, I. and Seldin, L. (2006) Diversity of Paenibacillus durus Strains Isolated from Soil and Different Plant Rhizospheres Evaluated by ARDRA and gyrB-RFLP Analysis. European Journal of Soil Biology, 42, 200-207. http://dx.doi.org/10.1016/j.ejsobi.2006.03.002

[47] Mehnaz, S., Baig, D.N. and Lazarovits, G. (2010) Genetic and Phenotypic Diversity of Plant Growth Promoting Rhizobacteria Isolated from Sugarcane Plants Growing in Pakistan. Journal Microbiology Biotechnology, 20, 1614-1623. http://dx.doi.org/10.4014/jmb.1005.05014

[48] Rosado, A.S., de Azevedo, F.S., da Cruz, D.W., van Elsas, J.D. and Seldin, L. (1998) Phenotypic and Genetic Diversity of Paenibacillus azotofixans Strains Isolated from the Rhizoplane or Rhizosphere Soil of Different Grasses. Journal of Applied Microbiology, 84, 216-226. http://dx.doi.org/10.1046/j.1365-2672.1998.00332.x

[49] Beneduzi, A., Peres, D., Vargas, L.K., Bodanese-Zanettini, M.H. and Passaglia, L.M.P. (2008) Evaluation of Genetic Diversity and Plant Growth Promoting Activities of Nitrogen-Fixing Bacilli Isolated from Rice Fields in South Brazil. Applied Soil Ecology, 39, 311-320. http://dx.doi.org/10.1016/j.apsoil.2008.01.006

[50] Holguin, G., Guzman, M.A. and Bashan, Y. (1992) Two New Nitrogen-Fixing Bacteria from the Rhizosphere of Mangrove Trees: Their Isolation, Identification and in Vitro Interaction with Rhizosphere Staphylococcus sp. FEMS Microbiology Ecology, 101, 207-216. http://dx.doi.org/10.1016/0168-6496(92)90037-T

[51] Betancourt, D.A., Loveless, T.M., Brown, J.W. and Bishop, P.E. (2008) Characterization of Diazotrophs Containing Mo-Independent Nitrogenases, Isolated from Diverse Natural Environments. Applied and Environmental Microbiology, 74, 3471-3480. http://dx.doi.org/10.1128/AEM.02694-07

[52] Yastrebova, O.V., Plotnikova, E.G., Anan'ina, L.N. and Demakov, V.A. (2009) Aerobic Spore-Forming Bacteria from the Region of Salt Mining. Russian Journal of Ecology, 40, 516-521. http://dx.doi.org/10.1134/S1067413609070108 